\title{
Prevalence of Soil-borne Diseases in Kalanchoe blossfeldiana Reveals a Complex of Pathogenic and Opportunistic Fungi
}

\author{
Kenneth Madriz-Ordeñana, ${ }^{1, \dagger}$ Hans Jørgen Lyngs Jørgensen, ${ }^{1}$ Andreea Balan, ${ }^{1}$ Daniel Madriz Sørensen, ${ }^{1}$ \\ Kai Lønne Nielsen, ${ }^{2}$ and Hans Thordal-Christensen ${ }^{1}$ \\ ${ }^{1}$ Department of Plant and Environmental Sciences, Faculty of Science, University of Copenhagen, DK-1871 Frederiksberg C, \\ Denmark \\ ${ }^{2}$ Knud Jepsen a/s, Skanderborgvej 193, 8382 Hinnerup, Denmark
}

\begin{abstract}
Greenhouse cultivation of ornamentals is subjected to a high incidence of soil-borne fungal pathogens. In Kalanchoe, these pathogens are responsible for root and stem rot, and for infection of the vascular tissue. Well-known soil-borne pathogens are believed to cause these diseases. Yet, a systematized survey of these pathogens is lacking for Kalanchoe produced commercially. Here, we studied the occurrence of soil-borne fungal pathogens associated with cultivation of Kalanchoe in Denmark and production of cuttings and stock plants in greenhouse facilities located in Turkey and Vietnam. Molecular identification of pathogens complemented mycological identification and pathogenicity testing of the soil-borne fungal

are the most prevalent pathogens associated with root and stem rotting and wilt of Kalanchoe under the conditions studied. Furthermore, the study showed that some of the pathogens are part of an infection complex comprising both primary and opportunistic fungal species. The fact that some of the pathogens were present in some regions, while absent in others, suggests how they move between greenhouse facilities on infected plant material. This study generated important information about the soil-borne fungal complex affecting Kalanchoe, which is useful for a better understanding of the biology of the disease and for designing control strategies.
\end{abstract} pathogens. This study revealed that the fungi Corynespora cassiicola, Thielaviopsis basicola, Fusarium solani, and F. oxysporum
Keywords: Thielaviopsis basicola, Corynespora cassiicola, Fusarium sp.
The ornamental plant Kalanchoe (Kalanchoe blossfeldiana Poelln.) is a popular succulent plant of great importance for the horticulture industry (ITC 2012; Rikken 2010). Commercial cultivation of Kalanchoe frequently takes place in nurseries under an optimized growth environment. Under these conditions, plants are subjected to attack by soil-borne fungal pathogens, which are responsible for rotting of roots, stems, and lower leaves of plants as well as vascular wilt (Wick 2017). Soil-borne pathogens have an important economic impact because infected plants usually appear asymptomatic during the initial growth stages, thus demanding the same resources as healthy plants, although they eventually become unsellable.

Several soil-borne pathogens that produce comparable disease symptoms in different hosts, including damping-off caused by Rhizoctonia spp. and Pythium spp., stem rot caused by Fusarium spp., and crown and root rot caused by Phytophthora spp., are also known to produce rotting of roots, crown, and stems in Kalanchoe (Wick 2017; Wick and Dicklow 1999). In addition, we recently identified the ubiquitous fungus Corynespora cassiicola as part of this group of soil pathogens affecting Kalanchoe production in Denmark (Madriz-Ordeñana et al. 2017). In general, the symptoms produced by soil-borne fungal pathogens in Kalanchoe are characterized by dark, necrotic lesions at the base of the plant, expanding to the stem and lower leaves. Highly affected plants show wilting, extensive root rot, and stunted growth. The management of root and stem diseases is difficult because early infections are either asymptomatic or

${ }^{\dagger}$ Corresponding author: K. Madriz-Ordeñana; kmor@plen.ku.dk

This research was supported by the Green Development and Demonstration Programme (GUDP) of the Ministry of Environment and Food of Denmark through project number 34009-16-1068.

The author(s) declare no conflict of interest.

Accepted for publication 23 April 2019.

(C) 2019 The American Phytopathological Society underground. Chemical control options are limited since protectant fungicides hardly reach the sites where these pathogens reside. Moreover, some pathogens are prone to develop resistance to systemic fungicides (Wick 2017). Meanwhile, biological control methods that involve the use of beneficial microorganisms applied to the soil may have the advantage of being able to colonize the plant roots and survive for longer periods in the rhizosphere, where they are expected to suppress root pathogens (Berendsen et al. 2012; Lareen et al. 2016; Zamioudis et al. 2013). However, biological control agents are still not fully accepted by all growers.

Soil-borne fungal pathogens belong to the soil microbial community, where they are part of a continuum of microorganisms ranging from saprophytes and pathogens to endophytes and symbionts (Aguilar-Trigueros et al. 2014; Malcolm et al. 2013). However, some of these fungi have the potential to invade the roots of suitable host plants and start a pathogenic lifestyle (Chapelle et al. 2016). When analyzing severely infected roots in commercial plant production, it is rare to find plants colonized by a single fungal species. Instead, the tissue is frequently colonized by several species forming a disease complex. Some of these mixed infections can be the result of opportunistic fungi and oomycetes invading the tissue already colonized by a pathogenic fungus. This is particularly frequent for necrotizing pathogens, which generate dead tissue that secondary fungi can subsequently occupy (Aguilar-Trigueros et al. 2014; Charkowski 2016). Mixed infections can also be synergistic, which results in augmented disease severity (Lamichhane and Venturi 2015; Peters and Grau 2002). Due to the similarity of the root and stem symptoms caused by soil-borne pathogens of Kalanchoe, visual assessment of the causal fungi can be difficult. Additionally, characterization of the aggressiveness of each fungal species can be masked during mixed infections.

Commercial production of Kalanchoe normally involves the use of clonal propagation, where cuttings are obtained from stock plants. The handling of plant material between different locations may increase the occurrence of distinct fungal species, potentially pathogenic to Kalanchoe. Previous attempts to diagnose soil pathogens associated with rotting of Kalanchoe roots and stems by visual assessment and microscopy suggested the presence of multiple fungi 
colonizing the tissue, making diagnosis uncertain (K. MadrizOrdeñana, K. Lønne Nielsen, and H. J. L. Jørgensen, unpublished data). However, in order to design strategies for controlling the pathogens associated with root and stems diseases, it is crucial to identify the organisms responsible for the primary infection and study their prevalence, pathogenicity, and virulence. Subsequent mapping of the origin and spread of these pathogens will allow introduction of control measures at their source in the propagation chain.

We hypothesize that some of the fungal species associated with root and stem rotting of Kalanchoe are primary necrotizing pathogens, whereas others subsequently thrive opportunistically in the necrotic tissue. In this study we aimed to: 1) perform a study of soil-borne fungi involved in the rotting of roots and stems of Kalanchoe plants during cultivation in a commercial nursery in Denmark; 2) analyze the occurrence of these soil-borne pathogens in samples of cuttings and stock plants obtained from Vietnamese and Turkish nurseries supplying the propagation material; and 3) define the most important soil-borne fungal pathogens affecting Kalanchoe under these production conditions by obtaining pure culture isolates and performing morphological and molecular identification as well as pathogenicity tests.

Monitoring the spread of putative opportunistic fungi alone or in conjunction with a primary pathogen in the plant tissue allowed us to distinguish the roles of some of these organisms in the disease complex. This is essential to design better strategies for disease management in Kalanchoe and other greenhouse crops.

\section{Materials And Methods}

Sampling of soil-borne fungi. All Kalanchoe samples were obtained during the period from October 2015 to October 2017. A total of 45 samples were collected in nurseries located in Hinnerup

Table 1. Fungal isolates obtained from Kalanchoe samples from different origins. Sampling was performed during a 2-year period and consisted of the particular plant part from where one or more isolates were obtained. The identification of the isolates was based on molecular methods and morphology as indicated.

\begin{tabular}{|c|c|c|c|c|}
\hline Sample & Plant part & Origin & Isolate & Identification \\
\hline $00^{\mathrm{a}}$ & Lower stem & Hinnerup, Denmark & $\begin{array}{l}\text { CP2285 } \\
\text { CP2283 }\end{array}$ & $\begin{array}{l}\text { Corynespora cassiicola }{ }^{\mathrm{b}, \mathrm{c}, \mathrm{d}} \\
\text { Fusarium solani }^{\mathrm{b}, \mathrm{d}}\end{array}$ \\
\hline 1.1 & Leaves & Hinnerup, Denmark & $11 \mathrm{~A}$ & Alternaria sp. $^{\mathrm{d}}$ \\
\hline $1.3^{\mathrm{a}}$ & Lower stem & Hinnerup, Denmark & $\begin{array}{l}13 \mathrm{~A} \\
13 \mathrm{C}\end{array}$ & $\begin{array}{l}\text { F. solani } \mathrm{b}^{\mathrm{b}, \mathrm{d}} \\
\text { Thielaviopsis basicola }^{\mathrm{c}}\end{array}$ \\
\hline 1.6 & Leaf petiole & Hinnerup, Denmark & $16 \mathrm{~A}$ & Fusarium fujikuroi $^{\mathrm{b}, \mathrm{d}}$ \\
\hline 2.1 & Lower stem & Da Lat, Vietnam & $21 \mathrm{~B}$ & C. cassiicola $^{\mathrm{b}, \mathrm{c}}$ \\
\hline $2.5^{\mathrm{a}}$ & Lower stem & Izmir, Turkey & $\begin{array}{l}25 \mathrm{~B} \\
25 \mathrm{C}\end{array}$ & $\begin{array}{l}\text { F. solani }{ }^{\mathrm{b}, \mathrm{d}} \\
\text { T. basicola }\end{array}$ \\
\hline $2.6^{\mathrm{a}}$ & Lower stem & Izmir, Turkey & $\begin{array}{l}26 \mathrm{~A} \\
\mathrm{CP} 2323 \\
26 \mathrm{C}\end{array}$ & $\begin{array}{l}\text { Fusarium oxysporum } \\
\text { T. basicold } \\
\text { T. basicola }{ }^{\mathrm{b}, \mathrm{c}, \mathrm{d}}\end{array}$ \\
\hline 3.1 & Lower stem & Hinnerup, Denmark & $31 \mathrm{E}$ & C. cassiicola $^{\mathrm{b}, \mathrm{c}}$ \\
\hline 4.1 & Lower stem & Da Lat, Vietnam & $41 \mathrm{C}$ & C. cassiicola $^{\mathrm{b}, \mathrm{c}}$ \\
\hline 4.3 & Lower stem & Da Lat, Vietnam & $43 \mathrm{~B}$ & C. cassiicola $^{\mathrm{b}, \mathrm{c}}$ \\
\hline 4.5 & Lower leaf & Da Lat, Vietnam & $45 \mathrm{C}$ & C. cassiicola $^{\mathrm{b}, \mathrm{c}}$ \\
\hline 4.7 & Middle stem & Da Lat, Vietnam & $\begin{array}{l}47 \mathrm{~A} \\
47 \mathrm{C}\end{array}$ & $\begin{array}{l}\text { Botrytis cinerea } a^{\mathrm{b}, \mathrm{d}} \\
\text { B. } \text { cinerea }^{\mathrm{b}, \mathrm{d}}\end{array}$ \\
\hline 4.8 & Middle stem & Da Lat, Vietnam & $48 \mathrm{C}$ & B. cinerea $^{\mathrm{b}, \mathrm{d}}$ \\
\hline 4.9 & Lower stem & Da Lat, Vietnam & $\begin{array}{l}49 \mathrm{~A} \\
49 \mathrm{~B} \\
49 \mathrm{C}\end{array}$ & $\begin{array}{l}\text { C. } \text { cassiicola }^{\mathrm{b}, \mathrm{c}} \\
\text { C. } \text { cassiicola }^{\mathrm{b}, \mathrm{c}} \\
\text { C. } \text { cassiicola }^{\mathrm{b}}\end{array}$ \\
\hline 4.10 & Lower stem & Da Lat, Vietnam & $\begin{array}{l}410 \mathrm{~A} \\
410 \mathrm{~B}\end{array}$ & $\begin{array}{l}\text { C. } \text { cassiicola }^{\mathrm{b}} \\
\text { C. } \text { cassiicola }^{\mathrm{b}}\end{array}$ \\
\hline 5.4 & Lower stem & Izmir, Turkey & $54 \mathrm{~B}$ & T. basicola ${ }^{\mathrm{b}, \mathrm{c}}$ \\
\hline $5.5^{\mathrm{a}}$ & Lower stem & Izmir, Turkey & $\begin{array}{l}55 \mathrm{~A} \\
55 \mathrm{~B} \\
55 \mathrm{C} \\
55 \mathrm{D}\end{array}$ & $\begin{array}{l}\text { T. } \text { basicola }^{\mathrm{b}} \\
\text { F. } \text { solani }^{\mathrm{b}} \\
\text { F. } \text { solani }^{\mathrm{b}} \\
\text { T. } \text { basicola }^{\mathrm{b}, \mathrm{c}}\end{array}$ \\
\hline $5.7^{\mathrm{a}}$ & Lower stem & Izmir, Turkey & $\begin{array}{l}57 \mathrm{~A} \\
57 \mathrm{~B} \\
57 \mathrm{C}\end{array}$ & $\begin{array}{l}\text { F. solani } \\
\text { F. solani } \\
\text { T. basicola } \\
\text { b,c }\end{array}$ \\
\hline $5.8^{\mathrm{a}}$ & Lower stem & Izmir, Turkey & $\begin{array}{l}58 \mathrm{~A} \\
58 \mathrm{~B}\end{array}$ & $\begin{array}{l}\text { T. } \text { basicola }^{\mathrm{b}, \mathrm{c}} \\
\text { F. solani }\end{array}$ \\
\hline 5.9 & Lower stem & Izmir, Turkey & $59 \mathrm{C}$ & T. basicola ${ }^{\mathrm{b}, \mathrm{c}}$ \\
\hline 5.10 & Middle stem & Izmir, Turkey & $\begin{array}{l}510 \mathrm{~A} \\
510 \mathrm{~B} \\
510 \mathrm{C}\end{array}$ & $\begin{array}{l}\text { F. oxysporum } \\
\text { F. oxysporum } \\
\text { b,d } \\
\text { F. oxysporum }\end{array}$ \\
\hline $6.1^{\mathrm{a}}$ & Middle stem & Hinnerup, Denmark & $\begin{array}{l}61 \mathrm{~A} \\
61 \mathrm{~B} \\
61 \mathrm{C} \\
61 \mathrm{D} \\
61 \mathrm{E} \\
61 \mathrm{~F} \\
61 \mathrm{G}\end{array}$ & 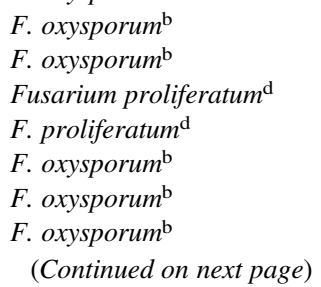 \\
\hline
\end{tabular}

\footnotetext{
${ }^{a}$ Mixed infection.

b Colony morphology and microscopy analysis.

c Species-specific PCR.

d ITS sequencing.
} 
(Denmark), Izmir (Turkey), and Da Lat (Vietnam) during the 2-year period (Table 1). Infected plants were recognized as wilted and stunted plants with stem, leaf, and root lesions. The samples primarily consisted of whole, uprooted plants that included part of the roots and adhering soil. Additionally, samples and cut tissues of plant organs, including leaves, roots, and flowers, showing necrotic lesions and rotting, were included. Samples were placed individually in plastic bags and transferred to the laboratory.

Fungal isolation. Plant samples were initially washed in tap water, thoroughly rinsed in sterile distilled water, and wiped off using tissue paper. Then, pieces of plant tissue showing lesions (1 to $5 \mathrm{~cm}$ in length) were placed on two layers of filter paper soaked with sterile distilled water in plastic petri dishes. The dishes were sealed with Parafilm and incubated for 1 to 5 days at room temperature (20 to $24^{\circ} \mathrm{C}$ ). For isolation of fungi from vascular tissues, stems were first surface-sterilized for $30 \mathrm{~s}$ in $70 \%$ ethanol, $45 \mathrm{~s}$ in $3 \%$ sodium hypochlorite, followed by rinsing five times for $1 \mathrm{~min}$ in sterile, deionized water. The stems were then cut either transversally or longitudinally to expose the infected tissue and then incubated under the same conditions as before.

Following incubation, each sample was observed by microscopy, and four to six single pieces of fungal mycelium were taken from different parts of the samples and transferred individually to potato dextrose agar (PDA) plates with $34 \mu \mathrm{g} / \mathrm{ml}$ chloramphenicol and $5 \mu \mathrm{g} / \mathrm{ml}$ tetracycline (Sigma-Aldrich). After overnight incubation at $28^{\circ} \mathrm{C}$, the plates were examined by microscopy and a single tip was cut from each growing mycelium and subcultured individually on new PDA plates until sporulation. Color, morphology, and growth features of fungal colonies on PDA plates were used for preliminary characterization of isolates. Microscopy of mycelium and propagation structures, micro- and macro-conidia and chlamydospores, as well as molecular methods (see below) were used for identification. The prevalence of the identified fungal species was calculated. Singlespore colonies were obtained from selected isolates. For this, serial dilutions of spore suspensions of each isolate were plated on $1.5 \%$ (wt/vol) water agar and incubated overnight at room temperature (20 to $24^{\circ} \mathrm{C}$ ). Individual, germinated spores were collected under the microscope and subcultured on PDA plates. Single-spore cultures were kept as glycerol stocks at $-80^{\circ} \mathrm{C}$.

Pathogenicity tests. Based on the overall prevalence of fungal species, 18 isolates from eight species were selected to test whether they were able to infect and produce the same symptomatology in Kalanchoe as previously observed in the collected samples. For all experiments, Kalanchoe cv. Margrethe was used due to its general high susceptibility to soil-borne pathogens (K. Madriz-Ordeñana, K. Lønne Nielsen, and H. J. L. Jørgensen, unpublished data). Cuttings were inoculated by root-dip inoculation (Freeman and Rodriguez 1993). For this, spore suspensions of the selected fungi were prepared by adding $10 \mathrm{ml}$ distilled sterile water to 3 -week-old PDA cultures and thoroughly scraping the surface with a plastic spatula. The suspensions

Table 1. (Continued from previous page)

\begin{tabular}{|c|c|c|c|c|}
\hline Sample & Plant part & Origin & Isolate & Identification \\
\hline 6.2 & Middle stem & Hinnerup, Denmark & $\begin{array}{l}62 \mathrm{~A} \\
62 \mathrm{~B} \\
62 \mathrm{C} \\
62 \mathrm{D}\end{array}$ & $\begin{array}{l}\text { F. oxysporum } \mathrm{b} \\
\text { F. oxysporum } \\
\text { b. oxysporum } \\
\text { b } \\
\text { F. oxysporum } \\
\text { b,d }\end{array}$ \\
\hline 8.1 & Lower stem & Hinnerup, Denmark & $\begin{array}{l}81 \mathrm{~A} \\
81 \mathrm{~B}\end{array}$ & $\begin{array}{l}\text { T. } \text { basicola }^{\mathrm{b}} \\
\text { T. } \text { basicola }^{\mathrm{b}}\end{array}$ \\
\hline 8.2 & Lower vascular tissue & Hinnerup, Denmark & $82 \mathrm{~A}$ & F. oxysporum ${ }^{\mathrm{b}}$ \\
\hline 8.3 & Lower vascular tissue & Hinnerup, Denmark & $83 \mathrm{~A}$ & F. oxysporum ${ }^{\mathrm{b}}$ \\
\hline 10.1 & Upper vascular tissue & Hinnerup, Denmark & $\begin{array}{l}101 \mathrm{~A} \\
101 \mathrm{~F}\end{array}$ & $\begin{array}{l}\text { F. oxysporum } \\
\text { F. oxysporum } \\
\mathrm{b}, \mathrm{d}\end{array}$ \\
\hline 10.2 & Lower vascular tissue & Hinnerup, Denmark & $\begin{array}{l}102 \mathrm{~B} \\
102 \mathrm{C}\end{array}$ & $\begin{array}{l}\text { F. oxysporum } \\
\text { F. oxysporum } \\
\text { b,d }\end{array}$ \\
\hline 11.1 & Lower stem & Hinnerup, Denmark & $111 \mathrm{~B}$ & F. oxysporum ${ }^{\mathrm{b}, \mathrm{d}}$ \\
\hline 11.2 & Lower stem & Hinnerup, Denmark & $\begin{array}{l}112 \mathrm{~A} \\
112 \mathrm{~B}\end{array}$ & $\begin{array}{l}\text { F. oxysporum } \\
\text { F. oxysporum } \\
\text { b }\end{array}$ \\
\hline 11.3 & Lower stem & Hinnerup, Denmark & $113 \mathrm{D}$ & F. oxysporum ${ }^{\mathrm{b}}$ \\
\hline 11.4 & Lower stem & Hinnerup, Denmark & $114 \mathrm{~B}$ & F. oxysporum ${ }^{\mathrm{b}}$ \\
\hline 11.5 & Lower stem & Hinnerup, Denmark & $115 \mathrm{~A}$ & F. oxysporum ${ }^{\mathrm{b}}$ \\
\hline 11.6 & Lower stem & Hinnerup, Denmark & CP2321 & F. oxysporum $\mathrm{b}, \mathrm{d}$ \\
\hline 11.7 & Lower stem & Hinnerup, Denmark & $\begin{array}{l}117 \mathrm{~A} \\
117 \mathrm{~B}\end{array}$ & $\begin{array}{l}\text { F. oxysporum } \mathrm{b} \\
\text { F. oxysporum } \\
\mathrm{b}\end{array}$ \\
\hline 11.8 & Upper vascular tissue & Hinnerup, Denmark & $\begin{array}{l}118 \mathrm{C} \\
118 \mathrm{D}\end{array}$ & $\begin{array}{l}\text { F. oxysporum } \\
\text { F. oxysporum } \\
\text { b,d }\end{array}$ \\
\hline 11.9 & Lower stem & Hinnerup, Denmark & 119D & F. oxysporum ${ }^{\mathrm{b}}$ \\
\hline 13.1 & Lower stem & Da Lat, Vietnam & $\begin{array}{l}131 \mathrm{~A} \\
131 \mathrm{C}\end{array}$ & $\begin{array}{l}\text { C. cassiicola } \\
\text { C. } \text { cassiicola }^{\mathrm{b}}\end{array}$ \\
\hline 13.2 & Lower stem & Da Lat, Vietnam & $\begin{array}{l}132 \mathrm{~B} \\
132 \mathrm{D}\end{array}$ & $\begin{array}{l}\text { C. } \text { cassiicola }^{\mathrm{b}} \\
\text { C. } \text { cassiicola }^{\mathrm{b}}\end{array}$ \\
\hline 13.3 & Lower stem & Da Lat, Vietnam & $\begin{array}{l}133 \mathrm{~A} \\
133 \mathrm{C} \\
133 \mathrm{D}\end{array}$ & $\begin{array}{l}\text { C. cassiicola } \\
\text { C. } \text { cassiicola }^{\mathrm{b}} \\
\text { C. } \text { cassiicola }^{\mathrm{b}}\end{array}$ \\
\hline 14.1 & Lower stem & Da Lat, Vietnam & $\begin{array}{l}141 \mathrm{~A} \\
141 \mathrm{~B}\end{array}$ & $\begin{array}{l}\text { C. } \text { cassiicola }^{\mathrm{b}} \\
\text { C. } \text { cassiicola }^{\mathrm{b}}\end{array}$ \\
\hline 14.2 & Lower stem & Da Lat, Vietnam & $\begin{array}{l}142 \mathrm{~A} \\
142 \mathrm{C}\end{array}$ & $\begin{array}{l}\text { C. } \text { cassiicola }^{\mathrm{b}} \\
\text { C. } \text { cassiicola }^{\mathrm{b}}\end{array}$ \\
\hline 14.3 & Lower stem & Da Lat, Vietnam & $\begin{array}{l}143 \mathrm{~A} \\
143 \mathrm{~B} \\
143 \mathrm{C} \\
143 \mathrm{D}\end{array}$ & $\begin{array}{l}\text { C. } \text { cassiicola }^{\mathrm{b}} \\
\text { C. } \text { cassiicola }^{\mathrm{b}} \\
\text { C. } \text { cassiicola }^{\mathrm{b}} \\
\text { C. } \text { cassiicola }^{\mathrm{b}}\end{array}$ \\
\hline 14.4 & Lower stem & Da Lat, Vietnam & $144 \mathrm{~B}$ & C. cassiicolab \\
\hline 14.5 & Lower stem & Da Lat, Vietnam & $145 \mathrm{D}$ & C. cassiicola $^{\mathrm{b}}$ \\
\hline
\end{tabular}


were filtered through two layers of gauze, the spore concentrations were determined with a hemacytometer and adjusted to $5 \times 10^{5}$ spores $/ \mathrm{ml}$. For isolates with poor sporulation, the inoculum included a mixture of spores and fungal mycelium scraped from 3-week-old PDA cultures. In this case, the nonfiltered suspension derived from each culture plate was sheared mechanically by vortexing for $30 \mathrm{~min}$ in $30 \mathrm{ml}$ of sterile water in a 50-ml centrifuge tube and subsequently diluted 10 times with sterile water. This procedure was followed each time in order to approach a standardized inoculation.

Plants for inoculation were produced from rootless cuttings, previously planted in vermiculite in the greenhouse for 10 to 12 days until newly developed roots were 0.5 to $1 \mathrm{~cm}$ long. The seedlings were then pulled out and the remaining vermiculite rinsed off the roots using deionized water. Subsequently, unless otherwise indicated, six cuttings were dip-inoculated by immersing the roots into a sterile plastic box containing $100 \mathrm{ml}$ spore suspension of each of the selected fungal isolates. Roots were maintained in the inoculum for $60 \mathrm{~min}$ at room temperature with constant shaking at $90 \mathrm{rpm}$. Controls consisted of six other cuttings that were treated the same way in sterile water. After treatment, the cuttings were directly transferred into commercial peat moss (Pindstrup Substrate no. 2, Pindstrup Mosebrug, Ryomgård, Denmark) and cultivated in the greenhouse (20 and $18^{\circ} \mathrm{C}$ day/night, $16 \mathrm{~h}$ light). The plants were examined regularly for symptoms for a period of up to 4 weeks, unless otherwise mentioned. Alternatively, detached leaves were used for drop inoculation where a $20-\mu l$ spore suspension $\left(5 \times 10^{5}\right.$ spores $\left./ \mathrm{ml}\right)$ was placed on the surface of the leaf using a micropipette while simultaneously producing a small wound with the pipette tip.

The ability of the fungal isolates to cause disease was evaluated by visual observation of plant size, necrosis, rot signs in the lower stem, and number of plants showing symptoms. Estimation of the effect of the infection was determined by recording fresh weight or by quantification of fungal biomass (see below). In order to comply with Koch's postulates, the putative pathogens were reisolated from the infected tissues and examined by microscopy for morphological identification. Identity of reisolated fungi was additionally confirmed by species-specific PCR and ribosomal ITS sequencing as described below.

Table 2. Sequences of oligonucleotide primers used in this study

\begin{tabular}{|c|c|c|c|}
\hline Primera $^{\mathbf{a}}$ & Primer sequence & Target & Reference \\
\hline ITS1 & $5^{\prime}$ - TCCGTAGGTGAACCTGCGG - $3^{\prime}$ & Ribosomal DNA ITS-region & White et al. (1990) \\
\hline ITS4 & $5^{\prime}$ - TCCTCCGCTTATTGATATGC- $3^{\prime}$ & & \\
\hline CoryITS-f1 & $5^{\prime}$ - GGCCTCGCCCCCTTCGAGAT -3' & Ribosomal DNA ITS-region & Mmbaga et al. (2015) \\
\hline CoryITS-r1 & $5^{\prime}-$ CCGACCCGCAGCCACTTCAG - $3^{\prime}$ & & \\
\hline CLOX1 & 5'- CAGCAAAGCATCAGACCACTATAACTC - $3^{\prime}$ & Calmodulin gene & Mulè et al. (2004) \\
\hline CLOX2 & $5^{\prime}$ - CTTGTCAGTAACTGGACGTTGGTACT - $3^{\prime}$ & & \\
\hline TB1 & $5^{\prime}-$ TATTCATTGCTGAGTGGC $-3^{\prime}$ & Ribosomal DNA ITS-region & Huang and Kang (2010) \\
\hline TB2 & $5^{\prime}$ - GGTTTTCCGGCATGTTAT - $3^{\prime}$ & & \\
\hline Fs-F4 & $5^{\prime}$ - GCCGTCCCCTAAATACAGTG -3' & Ribosomal DNA ITS-region & This study \\
\hline Fs-R4 & $5^{\prime}$ - AGAAGTTGGGGGTTTTACGG -3' & & \\
\hline $\mathrm{Kb}-\mathrm{F} 1$ & 5'- GCCCCTCCCATACGAGTTA -3' & Ribosomal DNA ITS-region & This study \\
\hline $\mathrm{Kb}-\mathrm{R} 1$ & $5^{\prime}$ - GCCTTAGAACCACCACTTGC $-3^{\prime}$ & & \\
\hline
\end{tabular}

a ITS: internal transcribed spacer; CoryITS: Corynespora cassiicola internal transcribed spacer; CLOX: Calmodulin Fusarium oxysporum; TB: Thielaviopsis basicola; Fs: Fusarium solani; Kb: Kalanchoe blossfeldiana.
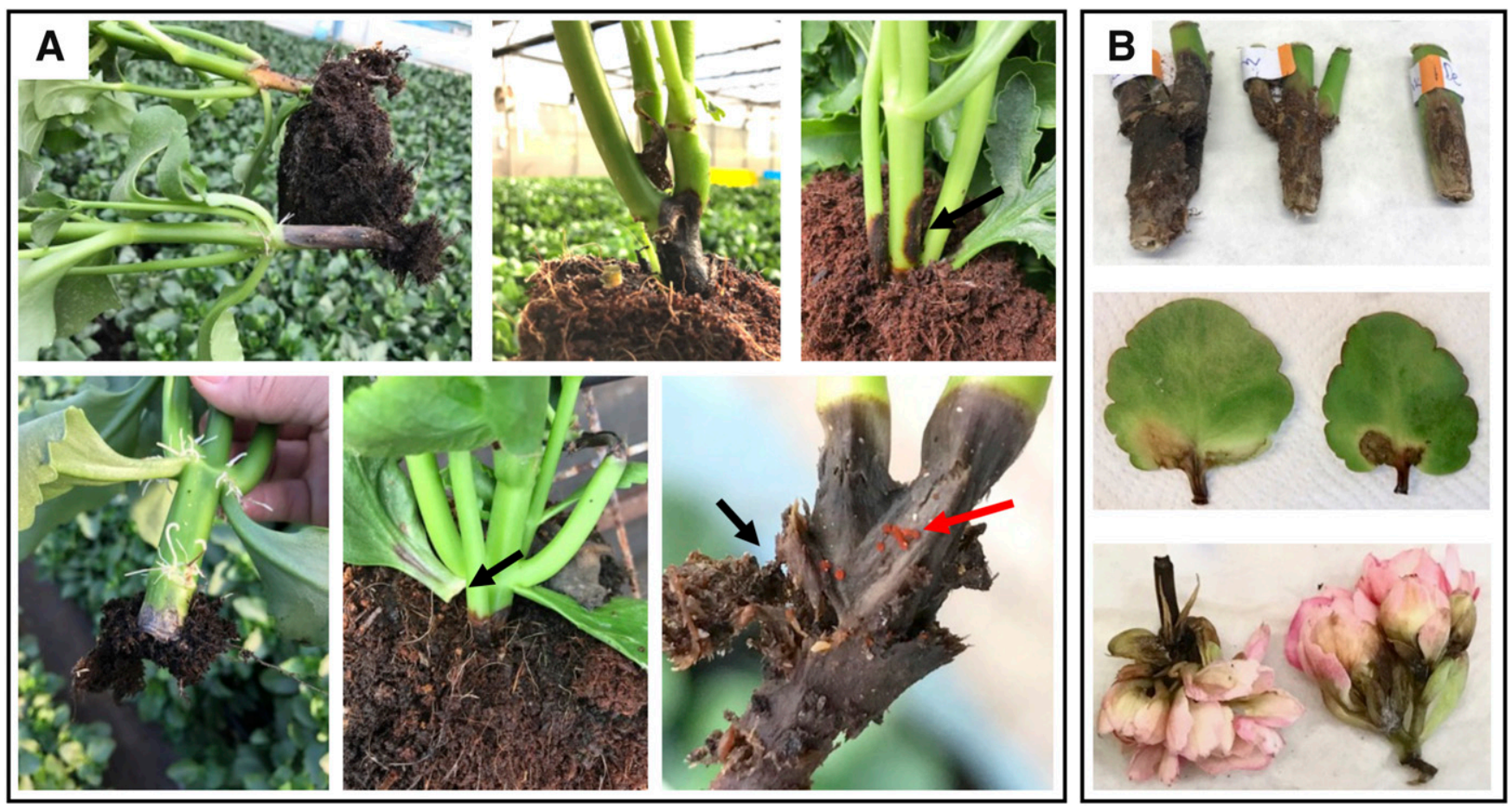

Fig. 1. General symptomatology observed on diseased Kalanchoe plants in this study. (A) Samples from whole plants showing root and stem necrosis. Detachment of leaves and tissue decay were frequently observed (black arrows). Fungal structures, such as perithecia (red arrow) were often seen. (B) Examples of cut tissues from stems, leaves, and flowers used to isolate fungal pathogens. 
DNA extraction, species-specific and quantitative PCR. Fungal genomic DNA was extracted from approximately $50 \mathrm{mg}$ fungal mycelium grown on PDA plates. DNA extraction from plant tissue was carried out from approximately $200 \mathrm{mg}$ of tissue. In both cases, the extraction was performed using DNeasy Plant kit according to instructions from the manufacturer (Qiagen $\mathrm{GmbH}$, Germany). Amplification of ribosomal DNA ITS region, species-specific PCR, and quantitative (q) PCR were performed using primers and PCR conditions detailed in Table 2. The primers used for amplification of Fusarium solani were designed based on the ITS sequence of isolate T70 (GenBank accession number FJ459978). Kalanchoe primers, needed for estimating the ratio of fungal DNA to plant DNA (see below), were designed from the ITS region of Kalanchoe blossfeldiana (accession number AJ231320.1, Gehrig et al. 2001) (Table 2). The design of primers was performed using the Primer3Plus web interface (Rozen and Skaletsky 2000). The specificity of $F$. solani and Kalanchoe primers was confirmed by PCR using genomic DNA from $T$. basicola, $F$. oxysporum, $C$. cassiicola, as well as plant genomic DNA. Biomass quantification was performed using the LightCycler96 System (Roche Diagnostics GmbH, Germany) and Brilliant III Ultra-Fast SYBR Green qPCR Master Mix, following the thermal profile recommended by the manufacturer (Agilent Technologies, California, U.S.A.). Fungal biomass was estimated by calculating the ratio of fungal DNA to Kalanchoe DNA. For this, qPCR amplification of serial dilutions from 1 to $10 \mathrm{ng}$ of pure genomic DNA from each organism was used to prepare standard curves, which were fit by linear regression. The amount of DNA was estimated by tracing the Ct-values against the known amount of DNA of the standard curves (Gachon and Saindrenan 2004). The standard curves and efficiency of amplification is presented in the corresponding figures.

Experimental design. The effect of T. basicola and C. cassiicola infection was quantified by recording the fresh weight of the aboveground part of the plants at 4 weeks after inoculation. For each pathogen, 15 inoculated and 15 water-treated control plants were used. The experiment was performed twice with similar results.

For monitoring tissue colonization by $F$. solani in mixed infection with $T$. basicola, the center of the adaxial part of three young, fully developed detached Kalanchoe leaves were first preinoculated with $T$. basicola isolate CP2323 by placing a $20-\mu 1$ spore suspension drop $\left(5 \times 10^{5}\right.$ spores $\left./ \mathrm{ml}\right)$ using a micropipette while simultaneously producing a small wound with the pipette tip on the surface of the leaf. The preinoculated leaves were placed on tissue papers soaked with sterile water and incubated for $24 \mathrm{~h}$ in sealed petri dishes. Subsequently, $F$. solani isolate CP2283 was inoculated by placing $20 \mu \mathrm{l}$ spore suspension $\left(5 \times 10^{5}\right.$ spores $\left./ \mathrm{ml}\right)$ on the same spot used for the preinoculation. The double-inoculated leaves were incubated for 6 days under high humidity in sealed petri dishes. The same double treatment procedure was used for inoculating each pathogen individually, but either F. solani or T. basicola was substituted by $20 \mu \mathrm{l}$ of water. Controls consisted of treatment with only water. For monitoring the proliferation of the fungi, 1-cm disks from around the sites of inoculation were sampled. Total genomic DNA extraction and qPCR monitoring was performed independently for each of the three leaves as described above. The experiment was performed four times with similar results.

F. oxysporum biomass was determined by $\mathrm{qPCR}$ at 0,7 , and 14 days after inoculation using three sets of genomic DNA extracted each from $1-\mathrm{cm}$ stem sections and using the primers and PCR conditions detailed in Table 2. The experiment was performed twice with similar results.

Statistical analyses. Data on plant fresh weight as well as pathogen biomass represent continuous variables. These data were analyzed by analysis of variance assuming a normal distribution using PROC GLM (SAS). Variance stability was checked for all analyses, and data were transformed when necessary. Only for the analysis of relative fungal biomass (Fig. 4E) transformation was necessary, and here square root transformation was used. Two treatments were compared in all analyses, and therefore, if the statistical analysis showed a significant difference, the two treatments were considered different and these differences are shown by a number of asterisks for each comparison: $* * *=$ significant at $P \leq 0.001 ; * *=$ significant at $0.001<P \leq 0.01 ; *=$ significant at $0.01<P \leq 0.05$; NS $=$ nonsignificant difference $P>0.05$. The experiments were performed at least twice with similar results, and only data for one of the experimental repeats are presented in the figures. All data were analyzed with SAS (release 9.4; SAS Institute, Cary, NC).

\section{Results}

Fungi isolated from samples. Samples of plants varying from newly planted cuttings to mature stock plants were collected (Table 1). The symptoms of the samples ranged from mild necrosis of stems and leaves to extensive rotting and root decay (Fig. 1A). Plants showing poor growth, wilting, and stunting were also sampled for possible vascular infection, which was subsequently confirmed by cross-sections exposing the infected vascular tissue. Other plant organs, i.e., stems, flowers, leaves, and roots were also included (Fig. 1B).

Following incubation of the infected tissues under high humidity, small pieces of mycelium were collected from four different areas of the tissue. The fungal mycelia were usually morphologically uniform within the samples. However, signs of mixed infections occurred as morphologically distinct mycelia emerged from individual plant samples (data not shown). A total of 86 fungal isolates were obtained from the samples studied (Table 1). Morphological features of fungal colonies growing on PDA plates were used for preliminary characterization. Species identification was performed by ITS sequencing. Additionally, species-specific PCR was used for verification of $T$. basicola and C. cassiicola isolates identified morphologically (Table 1). Following the identification of the 86 isolates, a clear

Table 4. Fungal isolates from Kalanchoe that were selected for pathogenicity tests. The tests were performed by root-dip inoculation unless otherwise indicated.

\begin{tabular}{llc}
\hline Fungal species & \multicolumn{1}{c}{ Isolates tested } & $\begin{array}{c}\text { Pathogenic on } \\
\text { Kalanchoe }\end{array}$ \\
\hline Corynespora cassiicola & $\mathrm{CP} 2285^{\mathrm{a}}, 21 \mathrm{~B}, 31 \mathrm{E}, 133 \mathrm{C}$ & Yes \\
Fusarium oxysporum & 26A, 114B, CP2321 & Yes \\
Thielaviopsis basicola & $13 \mathrm{C}, 25 \mathrm{C}, \mathrm{CP} 2323^{\mathrm{a}}, 26 \mathrm{C}$ & Yes \\
Fusarium solani $^{\mathrm{b}}$ & $\mathrm{CP} 2283^{\mathrm{a}}, 13 \mathrm{~A}, 25 \mathrm{~B}$ & $\mathrm{No}^{\mathrm{c}}$ \\
Other fungi $^{\mathrm{d}}$ & $11 \mathrm{~A}, 16 \mathrm{~A}, 47 \mathrm{~A}, 61 \mathrm{C}$ & No \\
\hline
\end{tabular}

a Single-spore isolates. GenBank accession numbers: CP2285 (KX458107), CP2321 (MK156395), CP2323 (MK158193), and CP2283 (MK156396).

b Prevalent, but not pathogenic on Kalanchoe when using root-dip inoculation, drop inoculation on wounded tissue.

${ }^{\mathrm{c}}$ Coinfection with $T$. basicola could result in colonization

d Alternaria spp., Fusarium fujikuroi, Botrytis cinerea, and $F$. proliferatum.

Table 3. Fungal isolates obtained in this study according to species and origin. The number of isolates of each fungal species in relation to the total isolates obtained during the sampling period is indicated as prevalence, which is expressed as percentage.

\begin{tabular}{|c|c|c|c|c|c|}
\hline Fungal species & Hinnerup, Denmark & Izmir, Turkey & Da Lat, Vietnam & Total & Prevalence \\
\hline Fusarium oxysporum & 27 & 4 & 0 & 31 & 36.0 \\
\hline Corynespora cassiicola & 2 & 0 & 26 & 28 & 32.6 \\
\hline Thielaviopsis basicola & 3 & 9 & 0 & 12 & 14.0 \\
\hline Fusarium solani & 2 & 6 & 0 & 8 & 9.3 \\
\hline Other fungi & 4 & 0 & 3 & 7 & 8.1 \\
\hline
\end{tabular}


prevalence of only four fungal species was found. The soil pathogens $C$. cassiicola and $F$. oxysporum were the most frequent as each of them accounted for approximately one-third of all isolates (Table 3). The common soil-borne pathogen T. basicola accounted for $14 \%$ of the isolates. Additionally, the ubiquitous fungus $F$. solani was regularly isolated and accounted for about $9 \%$. Notably, F. solani was recurrently found in mixed infections with $T$. basicola (Table 1). In these samples, red perithecia, corresponding to the fruiting bodies of $F$. solani, typically emerged in decaying tissues (Fig. 1A). Other known pathogens, including Botrytis cinerea, Alternaria spp., Fusarium fujikuroi, and Fusarium proliferatum, were rarely found and together accounted for about 8\% (Tables 1 and 3). The GenBank accession numbers of selected single-spore isolates are described in Table 4.

There was an association between fungal species and geographical sample origin. Thus, $C$. cassiicola was more consistently found in samples from Vietnam, whereas $T$. basicola and $F$. solani, often involved in mixed infections, were repeatedly found in samples originating from Turkey. The vascular pathogen $F$. oxysporum was found primarily in Danish samples and to a minor extent from Turkey (Tables 1 and 3). From the above findings, T. basicola, C. cassiicola, $F$. solani, and $F$. oxysporum were concluded to be the most prevalent
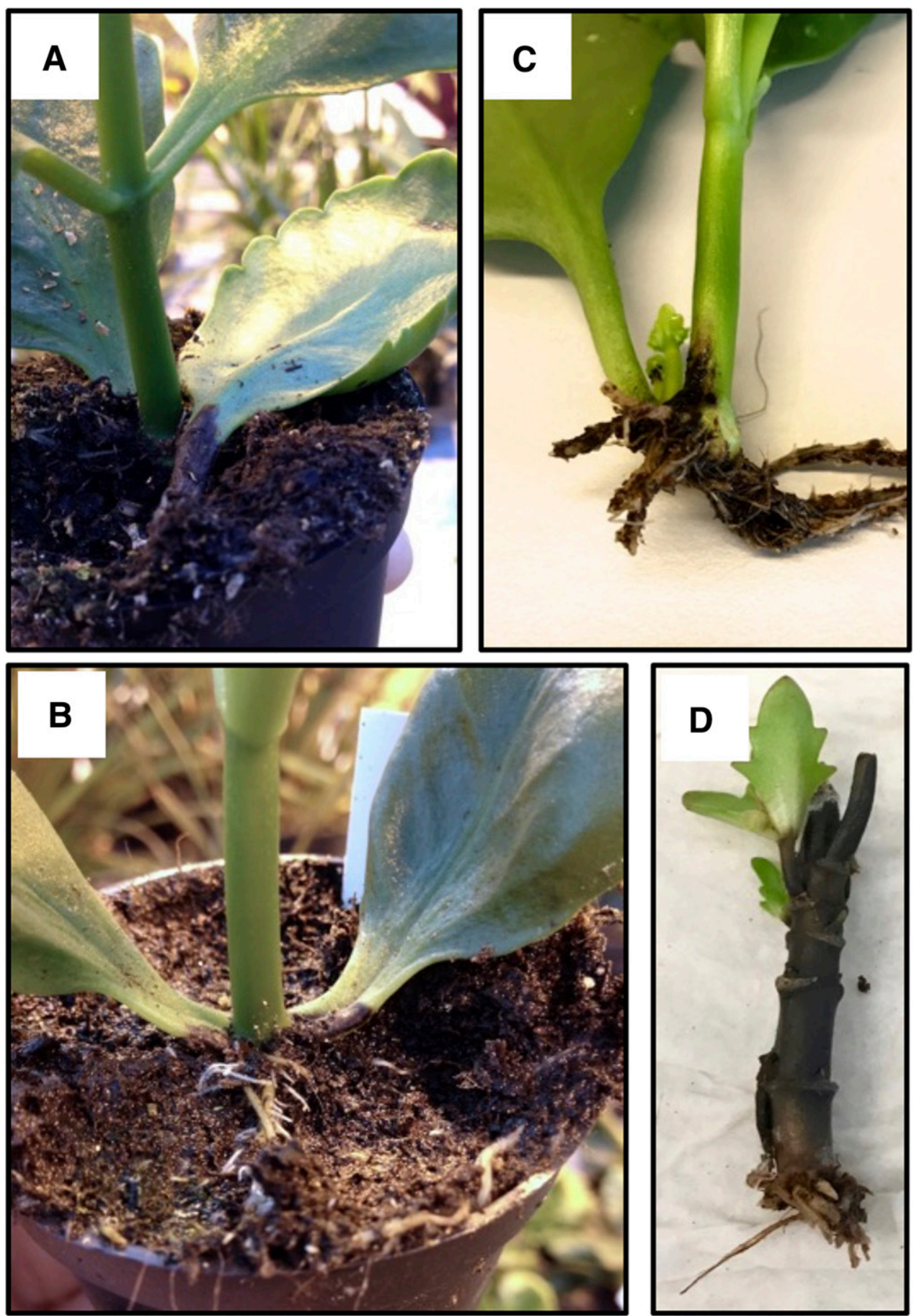
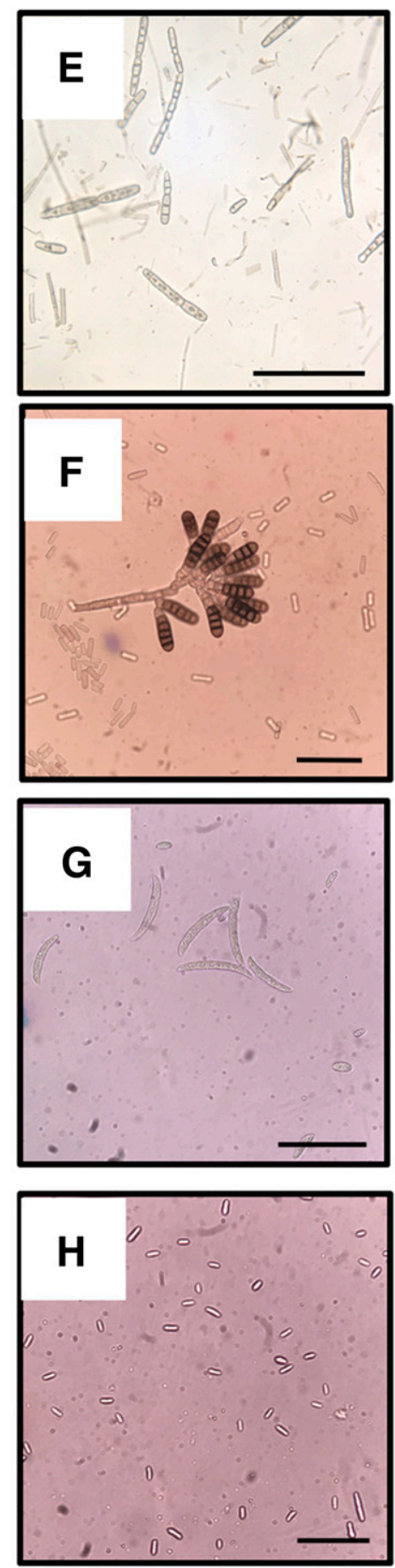

Fig. 2. Typical symptoms of basal stem and root infection in Kalanchoe plants 2 weeks after inoculation. Six 10-day-old Kalanchoe cuttings were root-dip inoculated with (A) Corynespora cassiicola or (B) Thielaviopsis basicola. (C) Root decay caused by T. basicola. (D) Advanced infection caused by Fusarium oxysporum. The identification of the pathogens was complemented by microscopy of propagation structures. (E) Conidial and hyphal morphology of C. cassiicola. (F) Conidia and chlamydospores of T. basicola. (G) Micro- and macroconidia of $F$. solani. (H) microconidia of $F$. oxysporum. Bar $=50 \mu \mathrm{m}$. 
fungi associated with necrosis and rotting of roots, stems, and lower leaves as well as wilting of Kalanchoe.

Pathogenicity tests. In order to assess the ability of these fungi to cause disease in Kalanchoe, several isolates of each species were selected for pathogenicity tests in the greenhouse (Table 4). Dipping of roots was used as the inoculation method, resembling the way soilborne fungal pathogens often infect roots. Inoculation with $T$. basicola and $F$. oxysporum gave clear symptoms at infection rates of nearly $100 \%$. Since the isolates of $C$. cassiicola showed poor sporulation on PDA plates under the conditions used, a mixture of spores and sheared mycelium was used for root-dip inoculation of this fungus achieving similar high infection rates.

C. cassiicola and T. basicola show similar symptomatology. During regular examination of the plants inoculated with $C$. cassiicola or T. basicola, signs of tissue necrosis initially appeared just under the soil surface at the base of the plants at 3 to 5 days after inoculation (dai). Subsequently, the necrotic area spread from the base of the stem, occasionally reaching the lower leaves within the first 2 weeks. When this happened, the leaves eventually detached (Fig. 2A and B). Severely infected plants showed root and stem decay (Fig. 2C). The initial development and characteristics of symptoms were similar for these two pathogens, making visual differentiation difficult to perform solely based on macroscopic symptomatology. However, morphological observations of pure cultures on PDA, microscopy of fungal structures (Fig. 2E to H), and ITS sequencing of each fungus reisolated from the infected tissues confirmed the identity of the pathogens. Additionally, species-specific PCR using total DNA extracted directly from tissues showing lesions confirmed the $C$. cassiicola and $T$. basicola infections (data not shown). The general effect of $C$. cassiicola and $T$. basicola on plant growth was evaluated by recording fresh weight of the aboveground part of plants at 4 weeks after inoculation with each pathogen. For both pathogens, the infected plants showed severe wilting, detachment of lower leaves, and general stunting. These pathogens furthermore reduced plant fresh weight by approximately $50 \%$ (Fig. 3).
F. solani opportunistically infects tissue colonized by $T$. basicola. Despite $F$. solani accounting for more than $9 \%$ of the isolates obtained, particularly in samples originating from Turkey and Denmark (Tables 1 and 3), root-dip inoculation using conidial suspensions of three isolates of $F$. solani (Table 4) failed to produce symptoms in Kalanchoe cuttings. Attempts to reisolate the fungus from inoculated cuttings were unsuccessful. Additional attempts to infect Kalanchoe with these isolates of $F$. solani through mechanically wounded leaves and stems by using drops of spore suspensions under high humidity conditions only produced localized lesions with no further spreading of necrosis (Fig. 4A). Therefore, the pathogenicity of the tested strains of $F$. solani on Kalanchoe could not be established. Nevertheless, since fruiting bodies (perithecia) of $F$. solani were regularly observed during sampling and the fungus was isolated from samples where T. basicola was also found (Fig. 1, Table 1), we performed a time-course study to monitor the proliferation of $F$. solani isolate CP2283 in detached Kalanchoe leaves, alone or following preinoculation with $T$. basicola isolate CP2323. Figure 4 shows the development of symptoms caused by $F$. solani inoculated alone or $24 \mathrm{~h}$ after a previous inoculation with $T$. basicola. At 2 and 6 dai, $F$. solani alone did not appear to colonize the leaf tissue outside the wound made during the inoculation (Fig. 4A and D). In contrast, symptoms observed when inoculating $F$. solani following an inoculation with $T$. basicola showed an expanded lesion at these time points (Fig. 4B). Here, gray mycelial growth typical of $T$. basicola was apparent in the lesions. In both cases, no $F$. solani fungal structures were visible at 6 dai. When inoculating $T$. basicola alone, expanding lesions showing mycelial growth were observed (Fig. 4C). In Figure 4E, qPCR monitoring showed that tissue inoculated with $F$. solani alone exhibited limited biomass increase of this fungus at 2 and 6 dai, which is consistent with the poor symptom development. However, when the tissue had been inoculated with $T$. basicola 24 h earlier, the qPCR data showed that the capability of $F$. solani to colonize was greatly promoted. Interestingly, the ability of $T$. basicola to colonize the tissue was not significantly affected by $F$. solani (Fig. 4E). The differences in biomass of $T$. basicola alone or in coinfection with $F$. solani possibly reflects variations in the inoculation step.
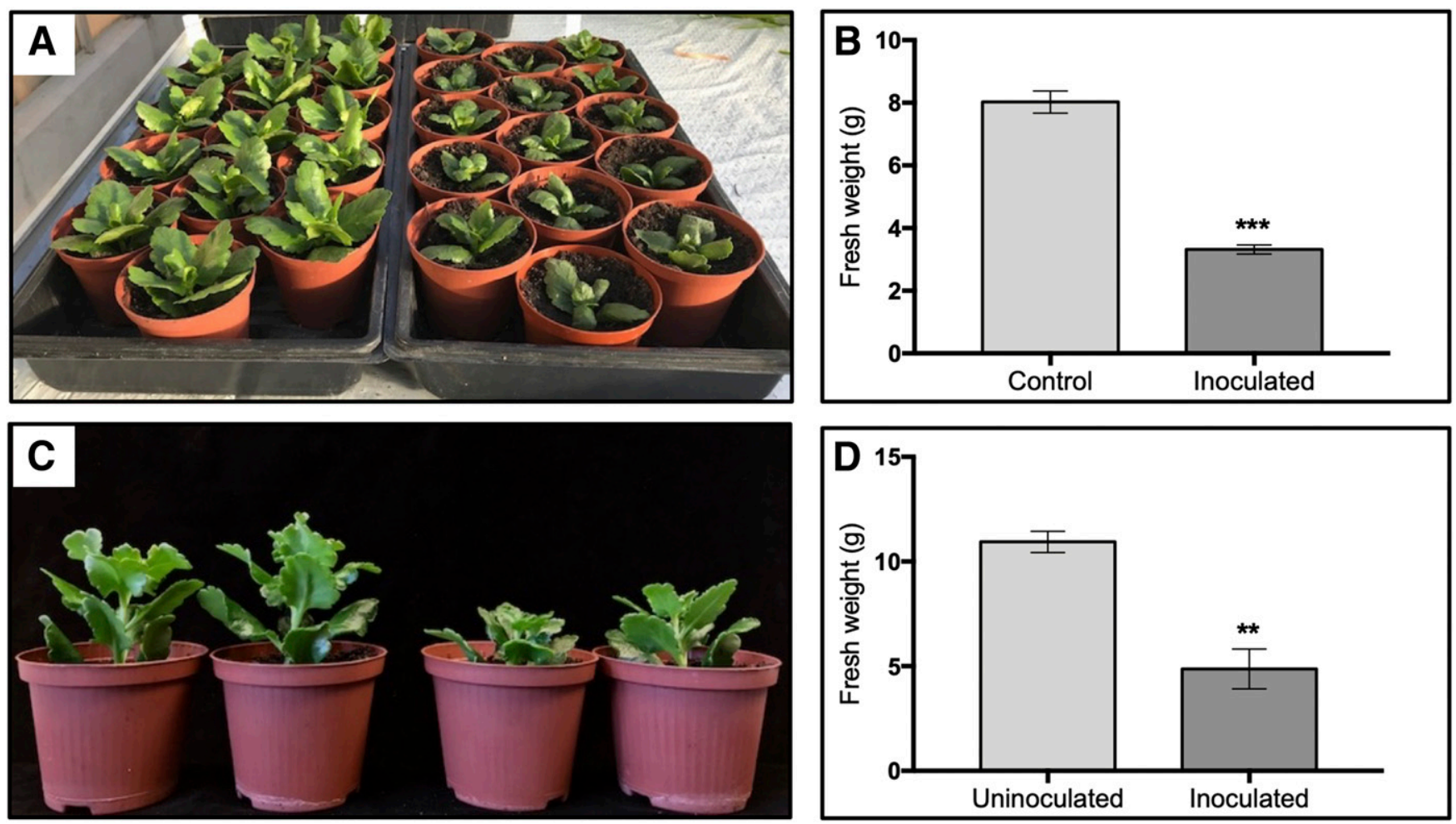

Fig. 3. Effect of Thielaviopsis basicola (isolate CP2323) and Corynespora cassiicola (isolate CP2285) on plant growth at 4 weeks after inoculation. Root dip inoculation of 10-dayold Kalanchoe cuttings with (A) T. basicola $(n=15)$ or $(\mathbf{C})$ C. cassiicola $(n=6)$ resulted in clear stunting of plants. Growth reduction was quantified by recording the fresh weight of the aboveground part of the plants inoculated with (B) T. basicola and (D) C. cassiicola.. Error bars represent standard error of the mean. ${ }^{* \star}$ indicates significant difference at $P \leq 0.001$ and ${ }^{* *}$ indicates significant difference at $0.001<P \leq 0.01$. 
F. oxysporum rapidly colonizes the vascular tissue of Kalanchoe. Early external signs of $F$. oxysporum infection were difficult to discern in root-dip inoculated Kalanchoe plants. The first visible symptoms were growth retardation and wilting approximately 14 dai. Stunting and wilting symptoms were followed by leaf detachment and general chlorosis and necrosis at 6 weeks after inoculation (Fig. 5A). The rate of $F$. oxysporum (isolate CP2321) fungal growth in the vascular tissue of Kalanchoe during the initial asymptomatic phases of infection was determined using qPCR at 0,7 , and 14 dai (Fig. 5B). Despite no obvious external symptoms, a clear increase in the amount of $F$. oxysporum biomass was found within the stems of the inoculated plants at 7 dai. A strong increase of fungal biomass was seen at 14 dai (Fig. 5B).

Other fungal species found. Other fungi were found occasionally in some of the samples (Table 1). Alternaria spp. (isolate 11A), Fusarium fujikuroi (isolate 16A), Botrytis cinerea (isolate 47A), and $F$. proliferatum (isolate $61 \mathrm{C}$ ) were tested, but none of the isolates were able to infect after root-dip inoculation (Table 4), drop-inoculation, or spraying spores on wounded tissue under high levels of humidity (data not shown).

\section{Discussion}

Early infection by soil-borne pathogens in Kalanchoe frequently goes unnoticed, which results in significant waste of resources as these plants are discarded when symptoms appear toward the end of the production period. Soil-borne fungal pathogens attacking roots and stems of Kalanchoe often produce similar symptomatology, making visual identification of the causal pathogen difficult (Pegg and Manners 2014). Horticultural plants produced in closed nurseries are particularly prone to infection by soil-borne pathogens (Paulitz and Bélanger 2001), and the existence of mixed infections adds more complexity to differentiating primary causal pathogens from opportunistic fungi (Aguilar-Trigueros et al. 2014). Thus, healthy greenhouse production of Kalanchoe requires knowledge of the pathogens present, particularly when dealing with disease complexes with diffuse symptoms. In the present study, we identified the causal fungal pathogens associated with root and stem rot and wilting of $\mathrm{Ka}-$ lanchoe in a specific production system. From 86 pure isolates obtained, there was a high prevalence of four fungal pathogens: $C$. cassiicola, T. basicola, $F$. oxysporum, and $F$. solani (Tables 1 and 3 ). These fungi are recognized, widespread, and problematic soilborne pathogens in many crop species. $C$. cassiicola is known as a common soil pathogen in tropical and subtropical regions (Dixon et al. 2009), and previous studies reported this fungus as a dominating pathogen of Kalanchoe in greenhouse production in Denmark (Madriz-Ordeñana et al. 2017). C. cassiicola was highly prevalent in samples from Vietnam, which is consistent with its tropical distribution. It is possible that the pathogen spreads to other regions through contaminated propagation material (Miyamoto et al. 2009). Endophytic variants of $C$. cassiicola have been reported (Déon et al. 2012), and this opens the possibility that this pathogen may be carried endophytically within the cuttings and subsequently shifts to a pathogenic lifestyle under certain conditions in the greenhouse (Delaye et al. 2013; Lopez et al. 2018; Schulz et al. 1999). Further studies will be required to elucidate this hypothesis. This study confirms our previous report (Madriz-Ordeñana et al. 2017) describing C. cassiicola as a destructive pathogen having the potential to seriously affect commercial Kalanchoe production.

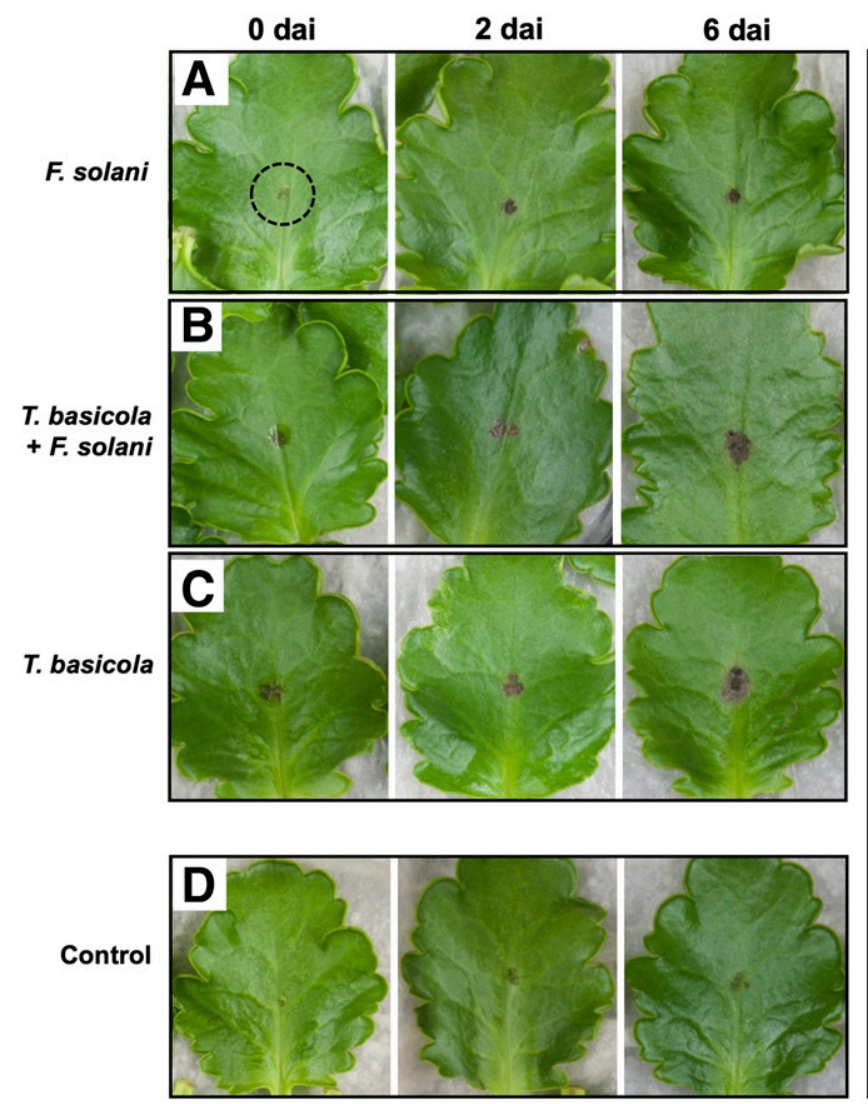

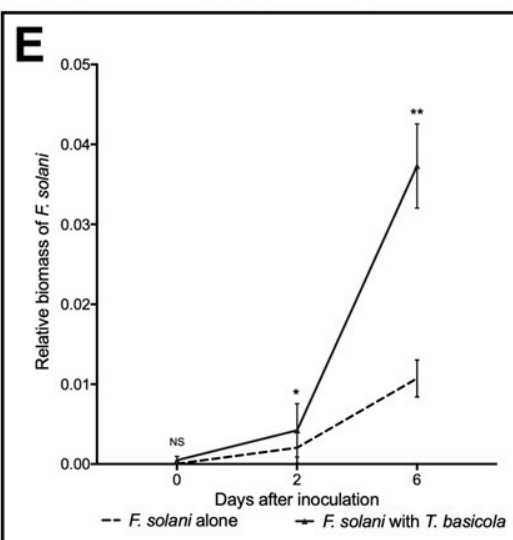

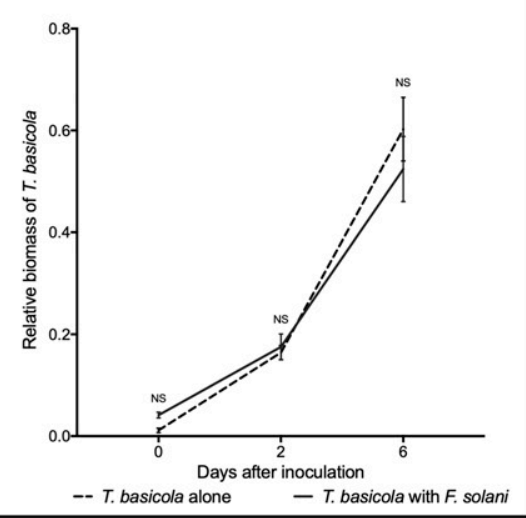

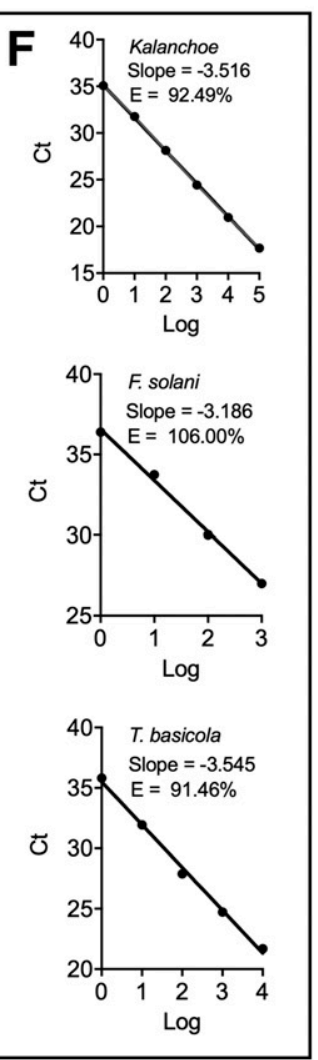

Fig. 4. Infection by Fusarium solani isolate CP2283 and Thielaviopsis basicola isolate CP2323 on detached Kalanchoe leaves at 0, 2, and 6 days after inoculation (dai). (A) Symptoms observed when F. solani was inoculated alone. (B) Symptoms when F. solani was inoculated on leaves preinoculated with $T$. basicola. (C) Symptoms of T. basicola when inoculated alone. (D) Noninoculated control leaves. (E) Relative fungal biomass of $F$. solani when inoculated alone or following the preinoculation with $T$. basicola (upper graph) and fungal biomass of $T$. basicola when inoculated alone or with $F$. solani (lower graph). The relative fungal biomass was determined from the same experiment by qPCR at the respective time points. $(F)$ Standard curves used for the calculation of amplification efficiency for each organism. The dashed circle in (A) illustrates the area sampled in all leaves. Error bars represent standard error of the mean of three independent leaves. ${ }^{* *}$ indicates significant difference at $0.001<P \leq$ 0.01 ; * indicates significant difference at $0.01<P \leq 0.05$; NS indicates nonsignificant difference at $P>0.05$. 
The soil-borne fungus T. basicola (synonym Chalara elegans) produces black root rot disease in many crops, including Kalanchoe, and shows a broad geographical distribution (CABI 2018; Farr and Rossman 2019; Yarwood 1981). T. basicola is particularly problematic under greenhouse conditions, where it spreads through soil and water as conidia. The fungus also produces resting spores (chlamydospores), which are capable of surviving in soil for up to 4 years (Papavizas and Lewis 1971; Riggs and Mims 2000). In the present study, $T$. basicola was regularly isolated from samples obtained from Turkey and Denmark, but not from Vietnam (Table 3). This suggests that the fungus spreads between regions through contaminated propagation material. Likewise, the ubiquitous fungus $F$. solani (synonym Nectria hematococca) was only found in samples from Denmark and Turkey (Table 3), which again indicates that the fungus moves through transfer of contaminated plant material. Despite this, we did not succeed in establishing pathogenicity of the selected $F$. solani isolates in Kalanchoe. Interestingly, F. solani was mainly isolated from mixed infection samples together with $T$. basicola (Table 1, Fig. 1). F. solani is a cosmopolitan fungus that includes saprophytes, plant pathogens, and facultative pathogens with a very complex structure of strains and formae speciales that have a wide host range (Coleman 2016). This fungus is even known as an opportunistic pathogen in immune-compromised humans (Zhang et al. 2006). F. solani can be found as endophyte, and some strains have been shown to protect plants from soil-borne diseases (Kavroulakis et al. 2007), whereas others promote the severity of other root diseases (Peters and Grau 2002). Due to the frequent mixed infections involving $F$. solani and $T$. basicola, we analyzed the ability of $F$. solani to colonize Kalanchoe in tissues where T. basicola was already established. $F$. solani was found to readily invade and proliferate in Kalanchoe leaves, but only when previously colonized by $T$. basicola in the tissue (Fig. 4). This corresponds to the observation of mixed infection with these two fungi in many of our samples (Table 1). In this case, $F$. solani appears to be a saprophyte that opportunistically invades the tissue already infected by a primary pathogen, in this case $T$. basicola. It remains to be investigated whether other necrotizing pathogens can promote the colonization of the $F$. solani isolates studied. From the current study, it is not possible to conclude whether the ability of $F$. solani to colonize the tissue is actively promoted by $T$. basicola or is merely an effect of more necrotized tissue being available in which $F$. solani can grow. The latter would be supported by the fact that $T$. basicola produces necrotizing phytotoxic compounds during pathogenesis (Tabachnik and DeVay 1980). On the other hand, the pathogenicity of T. basicola does not appear to be affected during coinfection with $F$. solani (Fig. 4E).

$F$. oxysporum is a problematic pathogen, severely infecting many crops throughout the world (Gullino et al. 2015; Pegg and Manners 2016). The fungus reproduces asexually and displays a vast number of strains and formae speciales and is therefore regarded as a species complex (Gordon 2017; Michielse and Rep 2009). There are also nonpathogenic forms of this soil-borne fungus. Some of these are endophytes and some have biocontrol properties (Waweru et al. 2014). $F$. oxysporum typically penetrates through the roots and systemically invades the vascular tissue causing obstruction of the xylem, which results in wilting and necrosis. Subsequently, the fungus spreads to adjacent tissues (Gordon 2017). We isolated F. oxysporum, not only from the vascular tissue of Kalanchoe, but also from advanced infections in leaves and flowers (Fig. 1). However, early infection of roots and vascular tissue could have passed unnoticed during sampling. Still, $F$. oxysporum was found in a total of 17 samples from where 31 isolates of this fungus were obtained (Tables 1 and 3). Most of these isolates derived from samples obtained from Denmark. However, since $F$. oxysporum was also found in samples from Turkey, we believe that there is a geographical spread of the pathogen, possibly due to the transfer of contaminated plant material from Turkey to Denmark. Since Kalanchoe cuttings and seedlings infected with $F$. oxysporum in commercial production do not show symptoms in the early stages of infection, timely eradication of infected plants cannot be performed, which leads to further spread of the pathogen and to waste of production resources.

In this study, it is interesting to note that four fungal pathogens were dominant, even when the samples were obtained from distinct geographical locations. The reason for this might be associated with how pathogen inoculum is spread, which we propose occurs mainly through contaminated plant propagation material that is transferred from location to location. Additionally, the sampling strategy was restricted to isolation of soil-borne pathogens, which would exclude strictly foliar pathogens from being found. Furthermore, the
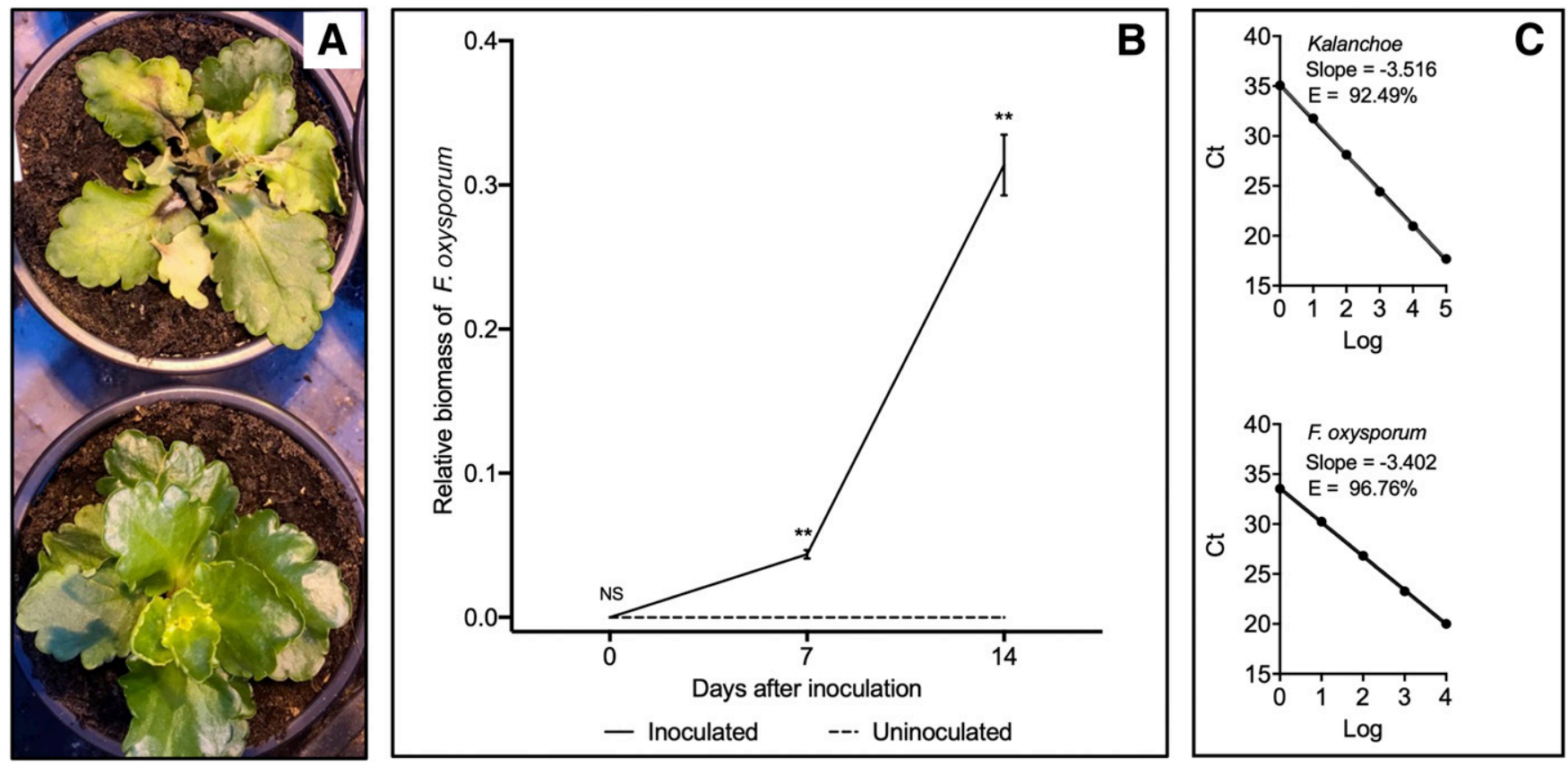

Fig. 5. Fusarium oxysporum infection of Kalanchoe. (A) The upper plant shows severe symptoms 6 weeks after the inoculation with F. oxysporum isolate CP2321. The lower plant is a noninoculated control plant. (B) Increase in the biomass of $F$. oxysporum in Kalanchoe stems. For each time point, three sets of stem sections $(1 \mathrm{~cm}$ long) taken just above the crown of six infected and six control plants were used. The sections within each set were pooled together and homogenized before DNA extraction. The ratio of fungal DNA to host DNA was calculated at 0,7 , and 14 days after inoculation. (C) Standard curves used for the calculation of amplification efficiency for each organism. Error bars represent standard error of the mean of the three sets $(n=3){ }^{* *}$ indicates significant difference at $0.001<P \leq 0.01$; NS indicates nonsignificant difference at $P>0.05$. 
diversity of microorganisms is reduced in monoculture systems under greenhouse conditions, which promotes selection of certain pathogens that become dominant (Huang et al. 2018; Zhou and Wu 2012).

Soil-borne pathogen diagnosis, based exclusively on observations of whole tissues with mixed infections, may lead to erroneous interpretations and incorrect application of control measures. This may occur when, for example, the presence of typical fruiting bodies is used as a sole indicator, without further complementary analysis. This is the case where perithecia of $F$. solani were observed in decaying tissues during mixed infections with $T$. basicola, which possibly acts as the primary pathogen (Table 1, Figs. 1 and 4). In these cases, a more exhaustive analysis is recommended.

Since commercial production of Kalanchoe commonly involves the transfer of vegetative propagation material between facilities located in different regions, we believe that it is crucial to include crop protection strategies that takes this into consideration. Thus, proper sanitary conditions for mother plants may lead to healthier cuttings.

Because the soil pathogens described in this study are problematic for commercial production of many plant species, including ornamentals and vegetables (Dik and Albajes 2002; Gullino et al. 2015; Paulitz and Bélanger 2001; Pegg and Manners 2014), we believe that the information generated here is also useful for designing strategies to control soil-borne fungal diseases in greenhouse plant production of other crops.

\section{Acknowledgments}

The collaboration of colleagues from Knud Jepsen a/s (Denmark), Queen Tarim (Turkey), and Hasfarm Young Plants (Vietnam), during the sampling of plant material is greatly appreciated.

\section{Literature Cited}

Aguilar-Trigueros, C. A., Powell, J. R., Anderson, I. C., Antonovics, J., and Rillig, M. C. 2014. Ecological understanding of root-infecting fungi using trait-based approaches. Trends Plant Sci. 19:432-438.

Berendsen, R. L., Pieterse, C. M. J., and Bakker, P. A. H. M. 2012. The rhizosphere microbiome and plant health. Trends Plant Sci. 17:478-486.

CABI. 2018. Chalara elegans (black root rot). Invasive Species Compendium. https://www.cabi.org/isc/datasheet/53616.

Chapelle, E., Mendes, R., Bakker, P. A. H., and Raaijmakers, J. M. 2016. Fungal invasion of the rhizosphere microbiome. ISME J. 10:265-268.

Charkowski, A. O. 2016. Opportunistic pathogens of terrestrial plants. Pages 147-168 in: The Rasputin Effect: When Commensals and Symbionts Become Parasitic, Advances in Environmental Microbiology 3. C. J. Hust, ed. Springer International Publishing AG, Switzerland.

Coleman, J. J. 2016. The Fusarium solani species complex: Ubiquitous pathogens of agricultural importance. Mol. Plant Pathol. 17:146-158.

Delaye, L., García-Guzmán, G., and Heil, M. 2013. Endophytes versus biotrophic and necrotrophic pathogens-are fungal lifestyles evolutionarily stable traits? Fungal Divers. 60:125-135.

Déon, M., Scomparin, A., Tixier, A., Mattos, C. R. R., Leroy, T., Seguin, M., Roeckel-Drevet, P., and Pujade-Renaud, V. 2012. First characterization of endophytic Corynespora cassiicola isolates with variant cassiicolin genes recovered from rubber trees in Brazil. Fungal Divers. 54:87-99.

Dik, A., and Albajes, R. 2002. Principles of epidemiology, population biology, damage relationships and integrated control of diseases and pests. Pages 69-81 in: Integrated Pest and Disease Management in Greenhouse Crops. R. Albajes, M. L. Gullino, J. C. van Lenteren, and Y. Elad, eds. Kluwer Academic Publishers, New York.

Dixon, L. J., Schlub, R. L., Pernezny, K., and Datnoff, L. E. 2009. Host specialization and phylogenetic diversity of Corynespora cassiicola. Phytopathology 99:1015-1027.

Farr, D. F., and Rossman, A. Y. 2019. Fungal Databases, U.S. National Fungus Collections, ARS, USDA. Retrieved March 1, 2019, from https://nt.arsgrin.gov/fungaldatabases.

Freeman, S., and Rodriguez, R. J. 1993. A rapid inoculation technique for assessing pathogenicity of Fusarium oxysporum f. sp. niveum and $F$. o. melonis on cucurbits. Plant Dis. 77:1198.

Gachon, C., and Saindrenan, P. 2004. Real-time PCR monitoring of fungal development in Arabidopsis thaliana infected by Alternaria brassicicola and Botrytis cinerea. Plant Physiol. Biochem. 42:367-371.

Gehrig, H., Gaußmann, O., Marx, H., Schwarzott, D., and Kluge, M. 2001. Molecular phylogeny of the genus Kalanchoe (Crassulaceae) inferred from nucleotide sequences of the ITS-1 and ITS-2 regions. Plant Sci. 160:827-835.

Gordon, T. R. 2017. Fusarium oxysporum and the Fusarium wilt syndrome. Annu. Rev. Phytopathol. 55:23-39.

Gullino, M. L., Daughtrey, M. L., Garibaldi, A., and Elmer, W. H. 2015. Fusarium wilts of ornamental crops and their management. Crop Prot. 73:45-49.
Huang, J., and Kang, Z. 2010. Detection of Thielaviopsis basicola in soil with realtime quantitative PCR assays. Microbiol. Res. 165:411-417.

Huang, Y., Xiao, X., Huang, H., Jing, J., Zhao, H., Wang, L., and Long, X.-E. 2018. Contrasting beneficial and pathogenic microbial communities across consecutive cropping fields of greenhouse strawberry. Appl. Microbiol. Biotechnol. 102:5717-5729.

ITC. 2012. Cut Flowers and Ornamental Plants. International Trade Centre. http:// www.intracen.org/uploadedFiles/intracenorg/Content/Exporters/Market_Data_ and_Information/Market_Insider/Cut_Flowers_and_Ornamental_Plants/Floriculture_ Monthly_M04_12.pdf.

Kavroulakis, N., Ntougias, S., Zervakis, G. I., Ehaliotis, C., Haralampidis, K., and Papadopoulou, K. K. 2007. Role of ethylene in the protection of tomato plants against soil-borne fungal pathogens conferred by an endophytic Fusarium solani strain. J. Exp. Bot. 58:3853-3864.

Lamichhane, J. R., and Venturi, V. 2015. Synergisms between microbial pathogens in plant disease complexes: a growing trend. Front. Plant Sci. 06:1-12.

Lareen, A., Burton, F., and Schäfer, P. 2016. Plant root-microbe communication in shaping root microbiomes. Plant Mol. Biol. 90:575-587.

Lopez, D., Ribeiro, S., Label, P., Fumanal, B., Venisse, J. S., Kohler, A., de Oliveira, R., Labutti, K., Lipzen, A., Lail, K., Bauer, D., Ohm, R. A., Barry, K. W., Spatafora, J., Grigoriev, I. V., Martin, F. M., and Pujade-Renaud, V. 2018. Genome-wide analysis of Corynespora cassiicola leaf fall disease putative effectors. Front. Microbiol. 9:1-21.

Madriz-Ordeñana, K., Jørgensen, H. J. L., Nielsen, K. L., and ThordalChristensen, H. 2017. First report of Kalanchoe leaf and stem spot caused by Corynespora cassiicola in Denmark. Plant Dis. 101:505-505.

Malcolm, G. M., Kuldau, G. A., Gugino, B. K., and Jimenez-Gasco, M. D. 2013. Hidden host plant associations of soilborne fungal pathogens: An ecological perspective. Phytopathology 103:538-544.

Michielse, C. B., and Rep, M. 2009. Pathogen profile update: Fusarium oxysporum. Mol. Plant Pathol. 10:311-324.

Miyamoto, T., Ishii, H., Seko, T., Kobori, S., and Tomita, Y. 2009. Occurrence of Corynespora cassiicola isolates resistant to boscalid on cucumber in Ibaraki Prefecture, Japan. Plant Pathol. 58:1144-1151.

Mmbaga, M. T., Kim, M.-S., Mackasmiel, L., and Klopfenstein, N. B. 2015. Differentiation of Corynespora cassiicola and Cercospora sp. in leaf-spot diseases of Hydrangea macrophylla using a PCR-mediated method. Can. J. Plant Sci. 95:711-717.

Mulè, G., Susca, A., Stea, G., and Moretti, A. 2004. Specific detection of the toxigenic species Fusarium proliferatum and $F$. oxysporum from asparagus plants using primers based on calmodulin gene sequences. FEMS Microbiol. Lett. 230:235-240.

Papavizas, G. C., and Lewis, J. A. 1971. Survival of endoconidia and chlamydospores of Thielaviopsis basicola as affected by soil environmental factors. Phytopathology 61:108-113.

Paulitz, T. C., and Bélanger, R. R. 2001. Biological control in greenhouse systems. Annu. Rev. Phytopathol. 39:103-133.

Pegg, K., and Manners, A. 2014. Soilborne root pathogens in production nurseries. Agriscience Queensland. Department of Agriculture, Fisheries and Forestry, Brisbane., https://www.ngia.com.au/Attachment?Action=Download\&Attachment_id=1848

Pegg, K., and Manners, A. 2016. Fact Sheet. Fusarium: A formidable nursery pathogen. Agri-science Queensland. Department of Agriculture, Fisheries and Forestry, Brisbane., https://www.ngia.com.au/Attachment?Action= Download\&Attachment id $=1839$

Peters, R. D., and Grau, C. R. 2002. Inoculation with nonpathogenic Fusarium solani increases severity of pea root rot caused by Aphanomyces euteiches. Plant Dis. 86:411-414.

Riggs, W., and Mims, C. W. 2000. Ultrastructure of chlamydospore development in the plant pathogenic fungus Thielaviopsis basicola. Mycologia 92:123-129.

Rikken, M. 2010. The European Market for Fair and Sustainable Flowers and Plants. BTC - Belgian Development Agency. http://www.befair.be/drupal_ files/public/all-files/brochure/The European Market for Fair and Sustainable Flowers and Plants.pdf.

Rozen, S., and Skaletsky, H. J. 2000. Primer3 on the WWW for general users and for biologist programmers. Pages 365-143 in: Bioinformatics Methods and Protocols: Methods in Molecular Biology. S. Krawetz and S. Misener, eds. Humana Press, New Jersey, USA.

Schulz, B., Rommert, A.-K., Dammann, U., Dammann, H.-J., and Strack, D. 1999. The endophyte-host interaction: A balanced antagonism? Mycol. Res. 103:1275-1283.

Tabachnik, M., and DeVay, J. E. 1980. Black root rot development in cotton roots caused by Thielaviopsis basicola and the possible role of methyl acetate in pathogenesis. Physiol. Plant Pathol. 16:109-117.

Waweru, B., Turoop, L., Kahangi, E., Coyne, D., and Dubois, T. 2014. Nonpathogenic Fusarium oxysporum endophytes provide field control of nematodes, improving yield of banana (Musa sp.). Biol. Control 74:82-88.

White, T. J., Bruns, T. D., Lee, S., and Taylor, J. W. 1990. Amplification and direct sequencing of fungal ribosomal RNA genes for phylogenetics. Pages 315-322 in: PCR Protocols: A Guide to Methods and Applications. M. Innis, D. H. Gelfand, J. J. Sninsky, and T. J. White, eds. Academic Press, San Diego.

Wick, R., and Dicklow, B. 1999. Diseases of Kalanchoë. Common Names of Plant Diseases. American Phytopathological Society, St. Paul, MN. https:// www.apsnet.org/edcenter/resources/commonnames/Pages/Kalancho\%C3\% AB.aspx 
Wick, R. L. 2017. Diseases of Kalanchoë. Pages 1007-1019 in: Handbook of Florist's Crops Diseases, Handbook of Plant Disease Management. R. J. McGovern and W. H. Elmer, eds. Springer International Publishing AG. Cham, Switzerland.

Yarwood, C. E. 1981. The occurrence of Chalara elegans. Mycologia 73:524-530.

Zamioudis, C., Mastranesti, P., Dhonukshe, P., Blilou, I., and Pieterse, C. M. J. 2013. Unraveling root developmental programs initiated by beneficial Pseudomonas spp. bacteria. Plant Physiol. 162:304-318.
Zhang, N., O’Donnell, K., Sutton, D. A., Nalim, F. A., Summerbell, R. C., Padhye, A. A., and Geiser, D. M. 2006. Members of the Fusarium solani species complex that cause infections in both humans and plants are common in the environment. J. Clin. Microbiol. 44:2186-2190.

Zhou, X., and Wu, F. 2012. Dynamics of the diversity of fungal and Fusarium communities during continuous cropping of cucumber in the greenhouse. FEMS Microbiol. Ecol. 80:469-478. 